\title{
To Be Rated or To Be Indexed: Corporate Governance Rating Experience in Borsa Istanbul
}

\author{
Burak Pirgaip1 ๑, Mehmet Berktay Akyüz² ๑
}

\begin{abstract}
We aim at answering whether it is more noteworthy for investors to attain or sustain corporate governance goals by examining how the market reacts towards announcements regarding corporate governance ratings (CGR) and corporate governance index (XCORP) including the firms listed in Borsa Istanbul within the sample period of 2007-2018 using a standard event study methodology. We found that, although both announcements produce relatively weak signals, joint announcements made upon XCORP inclusions along with first ever CGR (attainment) have more significance when compared to single announcements of subsequent CGR (sustainment) in the pre-event period. However, we also determined that the impact of subsequent CGR announcements in the post-event period was more profound. Our results revealed that the market anticipates XCORP inclusions whereas subsequent CGR are unexpected. Besides, the weak support for signaling hypothesis was considered to result from the obscuring effects of current legislation and market practices.
\end{abstract}

Keywords

Corporate governance, Corporate governance rating, Corporate governance index, Abnormal returns, Event study

\section{Introduction}

Corporate governance is concerned with organizational relationships that are set out to ensure proper and efficient allocation of duties, powers and responsibilities among a firm's management, its board of directors, its owners and other stakeholders (OECD, 2015). The nature and the level of interaction between these parties may vary from one firm to another, but it is built and updated in the glare of publicity when listed issuers are considered. In this regard, both corporate governance mechanisms and stock markets receive continuous feedback from each other. On one hand, capital market information enhances the ability of the organization to adopt changing demands and circumstances in a more effective and faster manner (Gillan, 2006); on the other hand, investors are willing to pay for good corporate governance, which translates into improvement in the value of stocks (Chang and Wei, 2011).

1 Corresponding Author: Burak Pirgaip (Assoc. Prof. Dr.), Hacettepe University, Department of Business Administration, Ankara, Turkey. E-mail: burakpirgaip@hacettepe.edu.tr ORCID: 0000-0001-8870-8502

2 Mehmet Berktay Akyüz (Ress. Asst.), Sabanci University, School of Management, İstanbul, Turkey. E-mail: berktayakyuz@gmail.com ORCID: 0000-0002-0638-7520

To cite this article: Pirgaip, B., \& Akyuz, M. B. (2020). To Be Rated or to Be Indexed: Corporate Governance Rating Experience in Borsa Istanbul. Istanbul Business Research, 49(2), 271-300. http://doi.org/10.26650/ibr.2020.49.0034 
From this standpoint, one question deserves closer attention: Is it more noteworthy to attain or sustain corporate governance goals in the eyes of investors? We aim at answering this question by drawing from signaling theory (Spence, 1973; Ross, 1977; Bhattacharya, 1979). The theory, within the context of corporate governance, postulates that disclosure of information regarding corporate governance actions conveys a signal of management quality or high reputation (see Toms, 2002; Musteen et al., 2010; Rahaman and Al Zaman, 2013 among others) as well as being perceived as a manifestation of the firm value or good performance (see Westphal and Zajac, 1998; Certo et al., 2001; Utrero-González and J. Callado-Muñoz, 2016 among others). Since corporate governance has a voluntary nature in substance, the signaling effect thereof also finds its roots in the literature pertaining to voluntary disclosures (Diamond, 1985). The basic premise, in any case, is that such disclosures can reduce the level of information asymmetry among stock market participants who then are expected to react positively to these signals of "differentiated" firms of "high-quality" (Fama, 1965; Jensen, 1978).

In this study, we focused on two types of disclosures attached to the corporate governance practice in Turkey: inclusion in the Corporate Governance Index (XCORP) which is developed by the Turkish stock exchange, i.e. Borsa Istanbul (BIST), and obtaining corporate governance ratings (CGR). Although these corporate actions have inherent commonalities as they are signs of good quality, they imply slightly -but significantly- different inferences in that the former indicates a one-time accomplishment of a distinctive level of corporate governance while the latter provides an overall assessment of the following efforts made towards the maintenance of this achievement. Furthermore, XCORP inclusion is, by regulation, warranted by an adequate level of CGR obtained by a given firm for the first time ever. Accordingly, CGR announcements other than the ones attached to XCORP inclusions once are subsequently made on a stand-alone basis in the years ahead. This is important to consider for a number of reasons. First, it is worth accounting for the possibility that the efficacy of a signal is influenced by earlier signals that have already granted a reputation to the firm (Heil and Robertson, 1991). That is, further achievements in corporate governance may be less or more valuable when the firm has already been included in the XCORP. As a corollary, another proposition would be that investors' expectations on the orientation of firms toward the future could change with time, meaning that their interpretations of the past and the future firm performance could be subject to change in different periods (George and Jones, 2000). This indeed suggests the management of a portfolio composed of different signals. Connelly et al. (2011) posit that different types of signals could communicate different messages and their interaction with each other should be explored. In concrete terms, inclusion of a firm in the XCORP could be regarded as an "activating signal" since it separates the firm from its competitors in terms of initiating good corporate governance principles within the organization, whereas obtaining a CGR is rather identified with a "pointing signal" that would stand for a confirmation of this acquired characteristic. All of these issues eventually would be reflected 
in the firm's value as markets provide differing feedback with respect to investor behavior by reacting to announcements differently.

Our analytical framework, therefore, was based on the standard event study methodology, which is commonly concerned with market reaction surrounding a corporate event based on cumulative abnormal return analysis (e.g. Lee, 2001; Cohen and Dean, 2005; Park and Mezias, 2005). In this way, we scrutinized the stock price reaction upon the announcements of improvements in the corporate governance of firms. We extended our analysis to include the impact of these announcements on trading volume as well. Our empirical findings revealed that abnormal returns and volumes following joint announcements of XCORP inclusions and first ever CGR were more pronounced than the ones associated with subsequent CGR in the pre-event period and on the announcement day. However, investors appeared to pay more for subsequent CGR announcements in the post-event period. Neither of the two signals were strong as a possible consequence of legislative impositions and imitative market practices.

The contribution of this study is two-folded. Primarily, we made a difference by analyzing the announcements effects of being included in XCORP and obtaining CGR in a comparative manner. Our approach allowed us to touch upon the literature on signaling theory from different angles owing to the fact that potential differences may exist in the market reactions to these separate events even if they are both driven by the same corporate governance mechanism. The Turkish market, in this respect, offers one of the unique settings where the prevailing corporate governance legislation includes specific provisions for both types of events. Secondarily, we spurred on academic discussion by drawing attention to index inclusion as a value adding facility for corporate governance practices.

Under this backdrop, the next section provides the conceptual and institutional background for our study. Section 3 and Section 4 introduce research data and methodology, respectively. Section 5 discusses the results of empirical analyses and Section 6 concludes the study.

\section{Conceptual and Institutional Background}

\section{Literature Review and Hypothesis Development}

A vast amount of research has been devoted to revealing the relationship between corporate governance and firm performance. Yet, the CGR concept has not been adequately addressed in this respect. Relevant studies primarily include investigations of whether firms perform better with good corporate governance ratings that yield complicated results. Drobetz et al. (2004), Garay and Gonzalez (2008), Morey et al. (2009), Renders et al. (2010), Arora and Sharma (2016), Bhatt and Bhatt (2017), and Ghosh (2018) find out that there is plausible national and international evidence to care about corporate governance in im- 
proving firm performance. Contrarily, researchers also argue that the relationship between corporate governance and firm performance is negative (Bauer et al., 2004; Bebchuk et al. 2009), weak (Epps and Cereola, 2008; Al-ahdal et al., 2020) or even non-existent (Singh and Davidson, 2003; Lehn et al. 2007). On the other hand, due to the fact that a stock exchange index product similar to XCORP can be rarely found in other jurisdictions ${ }^{1}$, "corporate governance index" has remained as an almost untouched domain to date. Rather, scholars use this nomenclature interchangeably with rating to describe self-constructed indices that stand for a subject firm's corporate governance score (Gompers et al., 2003; Foerster and Huen, 2004; Da Silva and Leal, 2005; Black et al., 2006; Cheung et al., 2011; Korent et al., 2014; Ararat et al., 2017; Arora and Bodhanwala, 2018; Kaur and Vij, 2018). This strand of literature is based on assessing the impact of the corporate governance level within a firm on performance and therefore is an extension of the abovementioned extant research on rating in substance. Apart from these studies, CGR activity per se has also been subject to criticism in many papers. For instance, Koehn and Ueng (2005) find that CGR are not reliable for investors at all. Donker and Zahir (2008) similarly put forward that a single-score-methodology may not be used as a simple measurement of corporate governance quality. Ertugrul and Hegde (2009) underline that a single score may not be informative enough about the whole complex corporate governance system. According to Daines et al. (2010), commercial CGR do not provide useful information for the market in terms of share prices. Interestingly, in a very recent study, Guest and Nerino (2020) replicate the analysis of Daines et al. (2010) and come up with contrasting findings with significant price impact of CGR in the case of downgrades in particular. Black et al. (2014) argue that probable reasons for this inconclusiveness in the CGR literature are construct invalidity, data unavailability and omitted variable bias. This argument has econometrically been verified by the authors indicating that "country-specific" governance indices, tailored to national legal infrastructure, have substantial power to predict market performance, while "common" indices across different countries suffer.

There is also a multitude of literature that employs event study methodology to corporate governance announcements most of which are related to signaling effects of institutional reforms such as appointment of independent board members, establishment of audit committees or enhancement of internal control mechanisms etc. Most of these studies find positive reactions (Chan-Lau, 2002; Picou and Rubach, 2006, Black and Khanna, 2007; Kang et al., 2009; Gupta and Fields, 2009; Fuenzalida et al., 2013), whereas there are some others that find negative (Zhang, 2007; Litvak, 2007; Daines et al., 2010) or insignificant (Rubach and Picou, 2005; Hodgson et al., 2011) reactions. Previous work focusing specifically on the

1 To the best of our knowledge, the Novo Mercado Index (IGCX) in Brazil and the Good Corporate Governance Index (GCGI) in Peru are the only ones that measure the performance of share prices of firms with an acceptable level of corporate governance (Ernst\&Young, 2016). Nevertheless, these indices are not based on commercial/official corporate governance ratings, but rather on self-assessments of firms or stock exchanges (Fuenzalida et al., 2013; Da Silva and Leal, 2005). 
Turkish stock market has a fragmented picture as well. The study by Bozcuk (2010) is one of the earliest research that investigates the market reaction to corporate governance rating reports during the four-year period from 2006 until the end of 2009, with a sample of 20 announcements. The author reports evidence of a statistically significant positive market reaction on the announcement day. However, as the author conveys, this reaction appears to be triggered by the simple act of having a corporate governance rating grade rather than the magnitude of the rating itself. Sakarya (2011), based on data pertaining to 11 companies which acquired their first CGR in 2009, also confirms a significant positive market reaction to ratings announcements. In another single year analysis, Yapa (2017) concludes that stock returns significantly increase in the aftermath of CGR announcements made in 2015 by 50 firms. Nevertheless, Sakarya et al. (2017) articulate that announcements regarding CGR grades had no impact on stock returns of 58 firms listed in Borsa Istanbul within the 2011-2015 period. In a contemporaneous study, Kavcar and Gümrah (2017) also reach the same conclusion for a sample of 55 firms in the period of 2007-2015. Lastly, Tuan and Borak (2019) center upon CGR changes instead of announcements between the years 2010 and 2014. The results of the study show that investors react negatively not only to the downgrades but, surprisingly, also to the upgrades. Negative reaction is also found to be significant in another study by Kılıç (2011) in which the investors of firms that are included in XCORP neglected to consider the inclusion event when they make their investment decisions. In another comparable attempt, Yavuz et al. (2015) argue that XCORP inclusion may have negative impacts on stock returns.

While these studies provide us the basis to find support for our research motivation that aims to differentiate the signaling power of XCORP inclusions and CGR obtainment in the market, we draw our primary inspiration from another branch of literature, which relates to the informational features of joint announcements. Joint announcements are announcements of multiple events that are made on the same day. Although we are not aware of any previous work that considers the joint announcement theme as part of corporate governance, a peculiar body of literature has evolved on the dividend announcement effects on information asymmetry conjoined with other corporate actions such as earnings or split announcements. On one hand, Kane et al. (1984) articulate that jointly made earnings and dividend announcements are complements of each other in that market does not evaluate them in isolation. Similarly, Eddy and Seifert (1992) argue that the stock price reaction to two contemporaneous announcements is greater than the reaction to just one signal. Alongside this US-based research, Easton (1991), Lonie et al. (1996), McCluskey et al. (2006), Dasilas et al. (2008), Anderson (2009), Al-Yahyaee et al. (2011) and Ozo and Arun (2019) confirm these findings in Australia, the UK, Ireland, Greece, New Zealand, Oman and Nigeria, respectively. In a different context, Kalaignanam and Bahadir (2013) also prove that jointly announced corporate name changes and business restructuring are significantly more informative than the sum of their individual effects. Venkatesh and Chiang (1986) investigate the joint announcement effects on the spread-setting behavior of dealers. 
They find that information asymmetry does not increase before joint announcements contrary to the strong increase in information asymmetry before subsequent announcements. Overall, these outcomes appear to contradict with the seminal theoretical analysis of Miller and Rock (1985), which reveals that concurrent announcements can serve as perfect substitutes for each other under certain conditions. On the other hand, Nayak and Prabhala (2001) show that dividends and splits are informational substitutes by disentangling the relative importance of dividend announcement effects from that of the other. A majority of previous research employs event study metrics to examine the abnormal returns for different announcement groups and regression metrics to analyze the interaction between announcements. However, in order to produce more robust results in the attempts of separating two types of information, the former methodology generally takes a conditional (e.g. Nayak and Prabhala, 2001) or an alternative (e.g. Anderson, 2009) form of event study, while the latter often makes use of regression analysis (e.g. Lonie et al., 1996; Al-Yahyaee et al., 2011; Ozo and Arun, 2019). Nevertheless, the underlying intuitions in both methodologies are, first, to conclude whether joint announcements convey more important news to the market, and second, to discover which of the two signals is more dominant in terms of its informational content. In cases where the tests of these intuitions show signs of difference in market reactions, the announcements would not be deemed as perfect substitutes.

Within these research streams, the paper most similar, both conceptually and methodologically, to ours is Dasilas et al. (2008). The authors adopt a standard event study approach to explore stock price and trading volume reaction to joint announcements of dividends and earnings and eventually evaluate the magnitude of reactions by means of tests of differences. Being inspired by this study, we adapted the joint announcement notion to our unique corporate governance setting and analyzed the importance of joint announcements of XCORP inclusions and underlying first ever CGR in relation to stand-alone CGR announcements made subsequently. Subsequent CGR, hereby, can be conceptualized as the successor CGR obtained at the nearest time following the year of XCORP inclusion.

In this purview, we built our discussion on various dimensions of signaling theory to help explain the influence of information asymmetries associated with the announcements of XCORP inclusion and CGR possession. We did so by distinguishing the signaling effects of one from the other by relying on a unique genre of literature on joint announcements. Our research hypothesis is that XCORP inclusion announcements, which are jointly made with first ever CGR, send signals which have influential power relative to individual subsequent CGR announcements as reflected in stock returns and trading volumes.

\section{Corporate Governance Requirements in Turkey}

Regulatory bodies in most parts of the world have seriously contemplated developing new or adapting generally accepted corporate governance codes or principles in their stock 
markets especially in the aftermath of accounting scandals 2 . CGR is one of the key tools used to encourage or enforce firms to align their existing corporate governance practices with the regulatory framework. Since investors -mainly institutional ones- base their portfolio decisions on CGR as well, disclosure of such information is voluntary to a substantial degree; however, it may become the subject of mandatory regulation in order to protect investors -mainly individual ones (Anand, 2006).

Turkey, as an emerging market, is one of the exceptional countries where corporate governance legislation relies on both a "comply or explain" approach and a "binding" set of rules. Nevertheless, that voluntary measures are applied in conjunction with mandatory requirements does not necessarily mean that they are in balance. Indeed, Capital Markets Board (CMB), the standard-setting body, shifted its voluntaristic view in the direction of a more obligatory stance in 2011 by tightening the compliance standards for large listed firms in its corporate governance code (OECD, 2013). This is also the case for CGR provisions. Although it is a discretionary activity carried out on demand, the methodology of ratings must be officially approved and the rating agency must be recognized by CMB. The rating facility not only complements the current legal infrastructure but also provides the basis for the XCORP. Essentially, XCORP acts as an incentive for firms to adopt high corporate governance standards (OECD, 2006). In this regard, when a firm obtains a minimum required rating, it is immediately included in XCORP. Alternatively, firms acquire their first CGR with the inherent intention of XCORP inclusion.

XCORP, by definition, measures the price and return performances of firms traded on BIST markets with a rating of a minimum of $7 / 10$ on aggregate and of a minimum of $6.5 / 10$ per sub-section. These sub-sections are titled as "Shareholders", "Public Disclosure and Transparency", "Stakeholders", and "Board of Directors". Weightings for each title are statutorily assigned by CMB. While original weightings were $25 \%, 35 \%, 15 \%$, and $25 \%$, they have been employed as $25 \%, 25 \%, 15 \%$, and 35\%, respectively, upon a revision that took place in 2014 . The CGR service is provided by rating agencies approved by CMB following an in-depth assessment of the agency's level of compliance with corporate governance principles.

\section{Data and Descriptive Statistics}

The first calculation of XCORP dates back to August 31 st, 2007 with an initial value of 48,082.17 and its closing price was 77,658.90 as of December 31st, 2018. We set our sampling period as $2007-20183$. The source of data utilized in this study is described in Table 1 :

2 Please see (OECD, 2017) for a detailed list of national corporate governance codes and principles.

3 Note that no inclusion in XCORP has taken place after 2018. 
Table 1

Source of data

\begin{tabular}{ll}
\hline Data & Source \\
\hline Share and index price information & Bloomberg \\
CGR announcements & TKYD and PDP \\
XCORP + CGR announcements & Bloomberg and PDP \\
Industry information & PDP \\
\hline
\end{tabular}

Notes: This table provides information regarding the source of data utilized in our analysis. TKYD denotes for Corporate Governance Association of Turkey, a non-profit organization aiming at developing and promoting adherence to corporate governance standards and guidelines in Turkey; PDP denotes for Public Disclosure Platform, an electronic system through which electronically signed notifications required by $\mathrm{CMB}$ and $\mathrm{BIST}$ are publicly disclosed.

Table 2 displays information regarding the announcements of index inclusions and CGR throughout the years with industrial specifications. As given in Panel A, the total number of joint announcements was 63, which is composed of simultaneous disclosures on XCORP inclusion and the first ever CGR reports 4 . The total number of CGR announcements, i.e. 461, in Panel B, included both first ever and subsequent CGR reports throughout our sampling period. Apparently, a great majority (about 86\%) of both types of announcements pertained to manufacturing and financial firms.

In our sampling process, we ended up with 60 firms after excluding firms which did not have subsequent CGR or which were included in the XCORP multiple times. In this way, we enabled ourselves to compare the joint announcements of XCORP and the first ever CGR with individual announcements of subsequent CGR of the same 60 firms.

Figure 1 portrays the average CGR scores on a year-by-year basis. What catches the eye in the figure is that the average CGR scores experienced a dramatic decline in 2014 due to the regulatory change in weightings of CGR sub-sections. Besides, "Board of Directors" and "Public Disclosure and Transparency" have always been the lowest and highest graded sub-sections, respectively. This explains the reason for the decline in 2014, since regulation simply requires a switch of weights (i.e. $35 \%-25 \%$ to $25 \%-35 \%$ ) between the former and the latter.

4 Though not reported, the amount of firms excluded from XCORP was 20. In our study, we ignored exclusions. The main reason is that exclusion of a given firm from XCORP does not stem from the fact that it has unsatisfactory corporate governance practices. Rather, firms are excluded due to delisting, restructuring or even nonrenewal of rating contracts in most of the cases. More concretely, the firms are immediately excluded from the XCORP when they publicly disclose their intention to be delisted or restructured. Even though, their market information is available until the exact date they are delisted or restructured, we prefered not to include them in our analysis for purification purposes. 
Table 2

Announcements Regarding Inclusions to XCORP and Obtaining CGR

\begin{tabular}{|c|c|c|c|c|c|c|c|c|c|}
\hline \multirow{2}{*}{\multicolumn{10}{|c|}{ Panel A. XCORP Announcements }} \\
\hline \multicolumn{9}{|c|}{ Panel A: XCORP Announcements } & \\
\hline Year & $\begin{array}{c}\text { An- } \\
\text { nounce- } \\
\text { ment }\end{array}$ & $\#$ & $\begin{array}{c}\text { Manufac- } \\
\text { turing }\end{array}$ & $\begin{array}{c}\text { Wholesale \& } \\
\text { Retail }\end{array}$ & $\begin{array}{c}\text { Min- } \\
\text { ing }\end{array}$ & $\begin{array}{l}\text { Construc- } \\
\text { tion }\end{array}$ & $\begin{array}{c}\text { Transportation } \\
\text { \& Telecommu- } \\
\text { nication }\end{array}$ & $\begin{array}{l}\text { Technol- } \\
\text { ogy }\end{array}$ & $\begin{array}{c}\text { Finan- } \\
\text { cial }\end{array}$ \\
\hline 2007 & \multirow{13}{*}{$\begin{array}{c}\text { XCORP }+ \\
\text { CGR }\end{array}$} & 7 & 5 & & & & & & 2 \\
\hline 2008 & & 6 & 3 & & & & & & 3 \\
\hline 2009 & & 11 & 3 & & & & 1 & 1 & 6 \\
\hline 2010 & & 7 & 2 & & 1 & & & & 4 \\
\hline 2011 & & 6 & 1 & 1 & & & & & 4 \\
\hline 2012 & & 7 & 1 & & & 1 & 1 & 1 & 3 \\
\hline 2013 & & 4 & 1 & & & & & & 3 \\
\hline 2014 & & 5 & 2 & & & & 1 & & 2 \\
\hline 2015 & & 6 & 2 & & & & & & 4 \\
\hline 2016 & & 1 & & 1 & & & & & \\
\hline 2017 & & 2 & & & & & & & 2 \\
\hline 2018 & & 1 & 1 & & & & & & \\
\hline Total & & 63 & 21 & 2 & 1 & 1 & 3 & 2 & 33 \\
\hline
\end{tabular}

Panel B: CGR Announcements

\begin{tabular}{|c|c|c|c|c|c|c|c|c|c|}
\hline \multicolumn{10}{|l|}{ Year } \\
\hline 2007 & & 6 & 5 & & & & & & 1 \\
\hline 2008 & & 12 & 8 & & & & & 1 & 4 \\
\hline 2009 & & 24 & 11 & & & & 1 & 1 & 11 \\
\hline 2010 & & 32 & 13 & 1 & 1 & & 1 & 1 & 15 \\
\hline 2011 & & 37 & 14 & 1 & 1 & & 1 & 2 & 19 \\
\hline 2012 & & 45 & 15 & 1 & 1 & 1 & 2 & 2 & 23 \\
\hline 2013 & CGR & 48 & 16 & 1 & 1 & 1 & 2 & 2 & 25 \\
\hline 2014 & & 52 & 18 & 1 & 1 & 1 & 2 & 2 & 27 \\
\hline 2015 & & 54 & 19 & 2 & 1 & 1 & 2 & 2 & 27 \\
\hline 2016 & & 51 & 18 & 2 & 1 & 1 & 2 & 2 & 25 \\
\hline 2017 & & 51 & 19 & 2 & 1 & 1 & 2 & 2 & 24 \\
\hline 2018 & & 49 & 18 & 2 & 1 & 1 & 2 & 2 & 23 \\
\hline Total & & 461 & 174 & 13 & 9 & 7 & 17 & 17 & 224 \\
\hline
\end{tabular}

Notes: This table provides information regarding the number of announcements regarding XCORP inclusion and CGR possession in the sampling period of 2007-2018. Panel A gives the number of joint announcements, while Panel B gives CGR announcement only. 


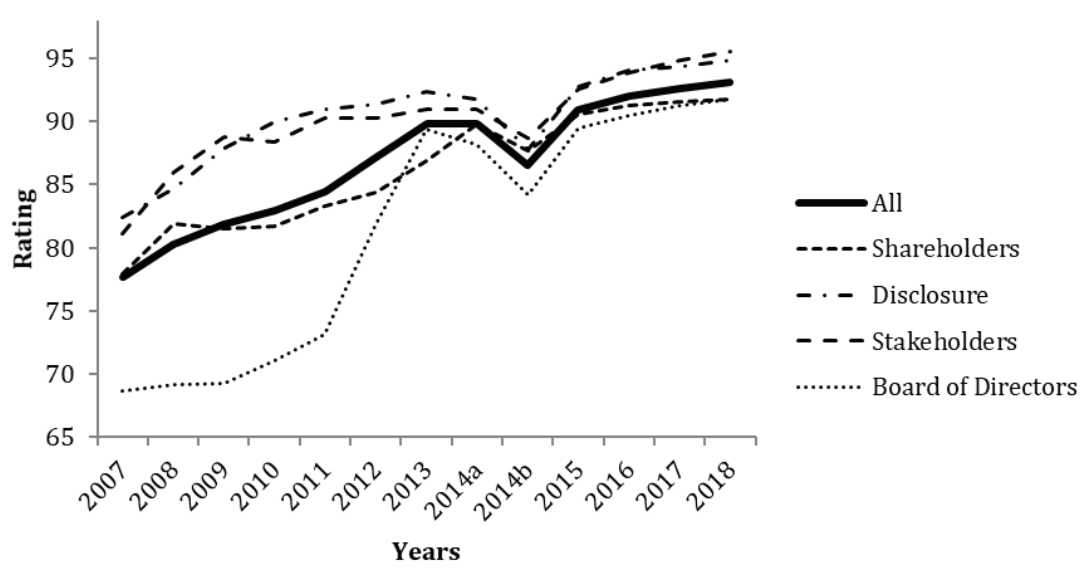

Figure 1. Average corporate governance rating scores over 100. 2014b denotes the rating reports updated in line with the new weighting scheme

When CGR changes were considered, we observed that upgrades in scores by far surpassed downgrades as pointed out in Table 3.

Table 3

CGR changes

\begin{tabular}{lccccc}
\hline Change & Main & (1) & (2) & (3) & (4) \\
\hline Upgrade & 355 & 353 & 327 & 333 & 343 \\
Downgrade & 33 & 36 & 61 & 55 & 46 \\
No Change & 9 & 8 & 9 & 9 & 8 \\
$\mathrm{~N}$ & 397 & 397 & 397 & 397 & 397 \\
\hline
\end{tabular}

Notes: This table provides information regarding CGR changes throughout the sampling period of 2007-2018. 63 out of 461 reports that constitute the first ever CGR reports were ignored. (1), (2), (3) and (4) correspond to "Shareholders", "Public Disclosure and Transparency", "Stakeholders" and "Board of Directors", respectively.

Descriptive statistics are reported in Table 4. Of the 2,850 trading days, only in rare cases did XCORP exceed and outperform the market, as proxied by BIST 100 index (XU100) 5 , in terms of price level (100 days) and cumulative daily returns (90 days). CGR scores ranged between 56.36 and 99.51. The highest correlation was found between the main and "Board of Directors" sub-section scores, while the lowest was between "Stakeholders" and "Board of Directors". Pairwise correlations between scores were all significant at $1 \%$.

5 XU100 was used as the main index for Borsa Istanbul Equity Market. It consists of 100 stocks selected among the stocks of companies traded on the Stars Market, where the companies that have relatively higher market capitalization of shares are traded. 
Table 4

Descriptive statistics

\begin{tabular}{|c|c|c|c|c|c|}
\hline \multicolumn{6}{|c|}{ Panel A: Preliminary Statistics } \\
\hline & Mean & Median & St. Dev. & Min & Max \\
\hline \multicolumn{6}{|c|}{ Price Level (TL) } \\
\hline XCORP & 61649.73 & $63,015.80$ & $18,587.75$ & $19,131.96$ & $104,760.00$ \\
\hline XU100 & $69,661.32$ & $71,609.57$ & $21,215.93$ & $21,228.27$ & $120,845.30$ \\
\hline \multicolumn{6}{|c|}{ Cumulative Daily Returns (\%) } \\
\hline XCORP & 36.20 & 48.96 & 42.50 & -85.43 & 105.95 \\
\hline XU100 & 50.81 & 62.84 & 43.41 & -76.19 & 123.37 \\
\hline \multicolumn{6}{|c|}{ Rating Scores (over 100) } \\
\hline Main & 88.89 & 90.76 & 5.29 & 70.4 & 97.02 \\
\hline (1) & 87.74 & 88.30 & 6.21 & 57.69 & 97.79 \\
\hline (2) & 92.10 & 92.87 & 4.88 & 73.27 & 99.47 \\
\hline (3) & 91.74 & 93.51 & 6.91 & 66.27 & 99.51 \\
\hline (4) & 84.68 & 88.60 & 9.41 & 56.36 & 97.82 \\
\hline \multicolumn{6}{|c|}{ Panel B: Correlation Matrix for Rating Scores } \\
\hline & Main & (1) & (2) & (3) & (4) \\
\hline Main & 1.00 & & & & \\
\hline (1) & 0.82 & 1.00 & & & \\
\hline (2) & 0.81 & 0.54 & 1.00 & & \\
\hline (3) & 0.70 & 0.49 & 0.56 & 1.00 & \\
\hline (4) & 0.86 & 0.62 & 0.55 & 0.41 & 1.00 \\
\hline
\end{tabular}

Notes: This table provides information regarding the descriptive features of our data. Panel A shows descriptive statistics for our sample. Panel B presents correlations between CGR scores. (1), (2), (3) and (4) correspond to "Shareholders", "Public Disclosure and Transparency", "Stakeholders" and "Board of Directors", respectively.

\section{Methodology}

We employed the standard event study methodology, which requires the calculation of abnormal returns. However, we extended our investigation to trading volume calculations as well. The analysis simply relies on the concept of market efficiency in that there is good reason to expect that impacts of an event will be reflected in stock prices in a short period in relatively efficient markets (MacKinlay, 1997). By doing so, we were able to detect stock price as well as trading volume reaction upon the announcements of improvements in the corporate governance of firms and test our hypothesis that obtaining CGR for the sake of $\mathrm{XCORP}$ inclusion (i.e. attaining corporate governance goals) is more important for investors than obtaining CGR individually (i.e. sustaining corporate governance goals).

On the other side, abnormal return was defined as the deviation from the expected return as formulated in Equation (1) below:

$$
A R_{i t}=R_{i t}-E R_{i t}
$$


where $A R_{\text {it }}$ is the abnormal, $R_{\mathrm{it}}$ is the actual and $E R_{\mathrm{it}}$ is the expected return of the shares of the firm $i$ in time $t . E R_{\mathrm{it}}$ was calculated by means of the following commonly used market model:

$$
R_{i t}=a+\beta x R_{m t}
$$

A proper determination of estimation and event windows is very important in event studies. Armitage (1995) emphasizes the trade-off between a shorter and longer window of estimation and argues that the average range of the estimation period is between 100 and 300 for daily studies. This length justifies a prior suggestion in Peterson's (1989) study in which a period of 20 to 121 days is also recommended for the event window. Previous research is varied in this regard. For instance, with respect to emerging markets, Dasilas et al. (2008) prefer to use a 200-days (100-days) estimation period for returns (trading volume) in the Greek market, while the estimation period of Black and Khanna (2007) is 240 trading days for the Indian market. Fuenzalida et al. (2013), however, choose 214 business days by considering the average number of days that a liquid security quotes in the Peruvian market. Event periods in these studies are set as 41-days $[-20,+20], 19$-days $[-9,+9]$ and 61-days $[-30,+30]$, respectively. Another, perhaps the most, important aspect of event studies is paying ultimate attention to confounding events during the windows under investigation. The longer the window, the harder it is to handle other events that have an impact on prices (McWilliams and Siegel, 1997). Having acknowledged these concerns and after a careful review of the literature for event studies in the Turkish market 6 , we decided to use an estimation period of 100 trading days $7[-110,+11]$ and an event period of 21 trading days $[-10,+10]$.

As suggested by Equation (2), we regressed the actual share returns $\left(R_{\mathrm{it}}\right)$ on the market portfolio returns $\left(R_{\mathrm{mt}}\right)$ for the estimation period. We obtained our parameter estimates ( $\alpha$ and $\beta$ ) from these regressions and computed the expected returns $\left(E R_{\mathrm{it}}\right)$ for each day in the event period in line with Equation (1). An XU100 index was used as the market proxy since it represents the whole market in terms of market capitalization. The rate of returns were calculated by dividing the difference between the closing price at a single day and at that of the previous day by the latter, i.e. $\left(P_{\mathrm{t}-} P_{\mathrm{t}-1}\right) / P_{\mathrm{t}-1}$. Cumulative abnormal returns (CAR), on the other hand, were calculated as follows:

$$
C A R_{i t}=\sum_{t=1}^{n} A R_{i t}
$$

We lastly derived average abnormal returns (AAR) and cumulative abnormal returns (CAAR) by taking the mean of the summed $A R_{\mathrm{it}}$ and $C A R_{\mathrm{it}}$ of the sample firms in the event period and employing parametric and non-parametric tests for the significance of both returns.

Please see Basdas and Oran (2014) and the references therein.

7 This also coincides with the viewpoint of the capital market regulatory body. Indeed, CMB requires a 6-month period in its specific regulations as a proxy for sound and efficient price formation. 
With regard to volume, we followed Harris and Gürel (1986) and used market-adjusted abnormal volumes calculated as follows:

$$
M A T V_{i t}=\frac{1}{n} \sum^{n} T V_{i}^{t}
$$

where

$$
T V_{i}^{t}=\frac{\frac{V_{i, t}}{V_{i}}}{\frac{V_{m, t}}{V_{m}}}
$$

In Equation (5), the nominator (denominator) denotes for the daily trading volume of a firm (the market) divided by its average trading volume in the estimation period. This volume ratio enters in the Equation (4) and enables the calculation of mean abnormal trading volumes on each event day as its cross-sectional averages on the same day. Under the null hypothesis of no trading volume effect, the volume ratio has an expected value equal to one.

Although we believe that our periods were long enough to capture the signaling effects as well as short enough to exclude confounding events, we generated abnormal returns and volumes for several event windows with different lengths.

\section{Results and Discussion}

\section{Price Reactions to Announcements of XCORP Inclusions and CGR}

\section{XCORP Inclusions and First Ever CGR}

In Table 5, we report AAR and CAAR alongside their significance tests surrounding the announcement day of XCORP inclusion based on the first ever CGR. We observed a positive ( 0.20 percent) but statistically insignificant price reaction on the joint announcement day. This was also when the highest level ( 0.51 percent) of CAAR was attained in the event window. In the pre-event period, a notable positive ( 0.59 percent $)$ reaction revealed itself six days prior to the announcement date. Despite two consecutive days of negative reaction afterwards, CAAR appeared to build up near Day 0 and turned out to be positive with another significantly positive reaction ( 0.56 percent) on Day -1 . However, these positive reactions were not justified by our non-parametric tests, which considered both the sign and magnitude of abnormal returns. Test results indicate that around 52 percent (Day -6) and 58 percent (Day -1) of the sample firms experienced statistically significant positive reactions. This implies that reported significant abnormal returns may be caused by outliers. To control for this possibility, we diagnosed abnormal returns for various windows. As laid out at the bottom of 
Table 5, CAAR in the $[-1,0]$ period was significantly positive in parametric and non-parametric terms. It appears that the possible outlier effects on Day -1 were absorbed in the positive reaction of the market to the joint announcement on Day 0. Our conclusion for the pre-event period is that an information leakage occured before XCORP inclusions. It is worth noting that Bozcuk (2010) also refers to a possibility of such a leakage before the CGR reports are publicly announced.

Table 5

Abnormal returns around the announcement date of inclusion in XCORP

\begin{tabular}{|c|c|c|c|c|c|}
\hline Day & AAR(\%) & t(AAR) & CAAR(\%) & t(CAAR) & Wilcoxon Test \\
\hline-10 & -0.40 & -1.51 & -0.40 & -1.51 & -1.32 \\
\hline-9 & -0.36 & $-1.70^{*}$ & -0.76 & $-2.11 * *$ & -1.38 \\
\hline-8 & 0.26 & 1.09 & -0.50 & -1.14 & 0.93 \\
\hline-7 & -0.20 & -1.12 & -0.70 & $-1.78^{*}$ & -1.14 \\
\hline-6 & 0.59 & $2.10 * *$ & -0.11 & -0.26 & 1.26 \\
\hline-5 & -0.07 & -0.35 & -0.18 & -0.42 & -0.20 \\
\hline-4 & -0.31 & -1.36 & -0.49 & -0.95 & -1.14 \\
\hline-3 & 0.12 & 0.39 & -0.37 & -0.55 & -0.06 \\
\hline-2 & 0.12 & 0.48 & -0.25 & -0.30 & 0.27 \\
\hline-1 & 0.56 & $1.88^{*}$ & 0.31 & 0.31 & 1.08 \\
\hline 0 & 0.20 & 0.97 & 0.51 & 0.50 & 0.74 \\
\hline 1 & -0.00 & -0.00 & 0.51 & 0.57 & -0.55 \\
\hline 2 & -0.12 & -0.45 & 0.38 & 0.38 & -1.18 \\
\hline 3 & -0.13 & -0.74 & 0.26 & 0.25 & -1.27 \\
\hline 4 & -0.25 & -0.86 & 0.01 & 0.01 & $-1.73 *$ \\
\hline 5 & -0.11 & -0.33 & -0.10 & -0.09 & -0.27 \\
\hline 6 & 0.13 & 0.49 & 0.03 & 0.02 & -0.24 \\
\hline 7 & -0.04 & -0.18 & -0.01 & -0.01 & -0.55 \\
\hline 8 & -0.07 & -0.27 & -0.08 & -0.07 & -0.51 \\
\hline 9 & -0.14 & -0.50 & -0.22 & -0.19 & -0.20 \\
\hline 10 & 0.06 & 0.20 & -0.16 & -0.14 & -0.65 \\
\hline & CAAR(\%) & $\mathbf{t}(\mathbf{C A A R})$ & \multicolumn{2}{|c|}{ Wilcoxon Test } & \\
\hline$[-5,-1]$ & 0.42 & 0.53 & \multicolumn{2}{|c|}{-0.37} & \\
\hline$[-2,0]$ & $0.88^{*}$ & 1.73 & \multicolumn{2}{|c|}{1,24} & \\
\hline$[-1,0]$ & $0.76^{* *}$ & 2.22 & \multicolumn{2}{|c|}{$1.89 *$} & \\
\hline$[-1,+1]$ & 0.76 & 1.53 & \multicolumn{2}{|c|}{0.89} & \\
\hline$[0,+1]$ & 0.20 & 0.39 & \multicolumn{2}{|c|}{-0.22} & \\
\hline$[0,+5]$ & -0.41 & -0.50 & \multicolumn{2}{|c|}{-0.93} & \\
\hline$[+1,+5]$ & -0.61 & -0.84 & \multicolumn{2}{|c|}{-1.35} & \\
\hline$[+1,+9]$ & -0.73 & -0.78 & \multicolumn{2}{|c|}{-0.63} & \\
\hline$[+1,+10]$ & -0.67 & -0.72 & \multicolumn{2}{|c|}{-0.68} & \\
\hline
\end{tabular}

Notes: This table displays the return effects of joint announcements of XCORP and first ever CGR. Day 0 is the announcement (event) date. $\operatorname{AAR}(\%)$ and CAAR $(\%)$ abnormal return and cumulative abnormal return on average. $t(A A R)$ and $t(C A A R)$ represent the $t$ statistics. Non-parametric Wilcoxon signed-rank test statistics show whether the z statistic of AAR is significantly different from zero. ** and * denote the significance level at $5 \%$ and $10 \%$, respectively. Sample includes 60 observations. 
On the other hand, the market showed insignificant reactions for an immediate adjustment in prices after the joint announcement date. Rubach and Picou (2005), Hodgson et al. (2011) and Kavcar and Gümrah (2017) raise the "insignificance" concern for the first ever CGR announcements as well. The authors' reasoning is that "good corporate governance" may not be an issue for investors since they are totally unaware of or unclear about the regulations or, conversely, they have already priced it as most of the rated firms are well institutionalized. However, it is very interesting that almost all of the abnormal returns were negative, even insignificant, in the post-event period dragging down CAAR from its higher levels to negative values. Zhang (2007), Litvak (2007), Daines et al. (2010), Kılıç (2011), Yavuz et al. (2015) and Tuan and Borak (2019) draw attention to the market's negative reaction towards corporate governance improvements in their research. Their findings are generally attributed to high compliance costs, but more importantly and more justifiably for the Turkish case, to the notion that attempts to comply with "good" corporate governance principles are deemed as "good on paper" only, since they are "imposed" to an extent rather than "internalized" properly8.

Based on our overall findings, we are of the view that XCORP inclusion is an anticipated event. The market already knows that the first ever CGR ends up with XCORP inclusion. As Bozcuk (2010) points out, it seems that this expectation is in line with the firms' outright confidence in attaining a high CGR to ensure XCORP inclusion insomuch that they, otherwise, would not be willing to go through such an onerous assessment. This may also pave the way for a leakage of information into the market. Abnormal returns, however, are likely to die out, even become negative, shortly after the inclusion announcement, which is probably because the announcement per se is not a strong signal at all to increase the awareness or attention of market participants. Instead, XCORP inclusion, as a corollary of the first ever CGR, appears to be considered as an easily imitable and a prerequisite activity in essence which is imposed on firms to obtain certain first-mover advantages ${ }^{9}$ granted by regulations (Rubach and Picou, 2005).

8 One could also argue that these negative figures are also contradictory with the literature regarding "index addition" that generally confirm positive reactions after addition [see Yildiz et al. (2017) and the references therein]. We think that inclusion in a corporate governance index such as XCORP is quite different from these stock index inclusions. One of the most important differences is that the body of index inclusion literature mainly explains relevant market reactions by referring to investment funds (particularly index funds) and their portfolio rebalancing activities required to avoid potential deviations from fund strategies. In contrast, this is unlikely to be true for the case of Turkey since there have been no funds established to specifically track the XCORP index so far.

9 In 2009, BIST started to apply a substantial discount on the listing fees of XCORP firms. But this practice was repealed in 2015. Since then, the number of firms included in XCORP has declined and inclusions eventually stopped after 2018 as mentioned in footnote 3. This is one brief indication of why firms would actually like to join XCORP. Yet more interestingly, anecdotal evidence shows that XCORP inclusion is perceived as one of the barriers to effective corporate governance by firm managers (TKYD, 2015: p. 6-7). This is confirmed by Ataman et al. (2017) in the way that there is a low relationship between CGR and management perceptions. 


\section{Subsequent CGR}

Market reaction to announcements of subsequent corporate governance ratings, which refer to the same group of 60 firms that have been included in the XCORP, are presented in Table 6 . On the announcement day, the reaction was slightly negative and insignificant. In the following days, however, the reaction was positive with some minor exceptions. The only statistically significant positive ( 0.60 percent) abnormal return was earned on Day +5 . CAAR built up positively even before starting from Day +1 , but Day +5 is the date when it became persistently significant until Day +10 ; the date CAAR began losing its significance. As suggested by the results that encompass several windows, it is apparent that one can earn significant CAAR throughout the post-event period. Non-parametric tests provided significant support for these findings as well ${ }^{10}$. These results concur with the ones obtained by Picou and Rubach (2006), Bozcuk (2010), Sakarya (2011), Fuenzalida et al. (2013) and Yapa (2017). Most of all, it is possible to ascribe the 5-day-delayed significant reaction to the lack of elucidation of the substance of CGR in the announcements, which would require some time for investors to obtain relevant information by means of a self-investigation (Picou and Rubach, 2006; Bozcuk, 2010)

In the pre-event period, however, there were no significant abnormal return values other than the marginally negative ones obtained on Day -10 (-0.41) and Day -3 (-0.46). Hence, our analysis suggests that there was almost no information leakage ${ }^{11}$ about subsequent CGR announcements, which contrasts with the pattern observed in the case of joint ones. Our inference is that CGR announcements are essentially unanticipated events, i.e. an upgrade or a downgrade is possible. Figure 2 depicts the CAAR data reported in Table 5 and Table 6.

10 Note that subsequent CGR are the successor ones obtained at the nearest time following the year of XCORP inclusion. We repeated our analysis by considering all subsequent CGR obtained throughout the sampling period. The results were qualitatively unchanged. Moreover, we made another robustness check by excluding CGR with downgrades from the analysis. As put in Table 3, CGR scores may also indicate a decrease, rather than an increase. This is worth considering because the market may react to negative news differently (Kouwenberg and Phunnarungsi, 2013). Indeed, CGR updates with respect to the new weightings imposed by CMB in 2014 resulted in significant downgrades and market reaction to the corresponding announcements was found to be consistently negative in the post-event period with high significance levels. Nevertheless, they did not have a significant impact on our results either. Data are available on request.

11 One can argue that the negative abnormal returns in the pre-event period may be associated with downgrades in subsequent CGR. However, as discussed in footnote 10, results remained unchanged when we excluded CGR with downgrades from our analysis. 
Table 6

Abnormal returns around the announcement date of subsequent $C G R$

\begin{tabular}{cccccc}
\hline Day & AAR(\%) & t(AAR) & CAAR(\%) & t(CAAR) & Wilcoxon test \\
\hline-10 & -0.41 & $-1.93^{*}$ & -0.41 & $-1.93^{*}$ & $-2.05^{* *}$ \\
-9 & 0.08 & 0.36 & -0.33 & -0.97 & 0.17 \\
-8 & 0.16 & 0.78 & -0.17 & -0.48 & 0.46 \\
-7 & 0.11 & 0.60 & -0.06 & -0.14 & 0.21 \\
-6 & -0.16 & -0.63 & -0.22 & -0.49 & -1.23 \\
-5 & -0.10 & -0.52 & -0.32 & -0.67 & -1.01 \\
-4 & -0.07 & -0.24 & -0.39 & -0.68 & -0.23 \\
-3 & -0.46 & $-1.66^{*}$ & -0.85 & -1.20 & -1.27 \\
-2 & -0.03 & -0.09 & -0.88 & -1.04 & 1.25 \\
-1 & 0.20 & 0.84 & -0.68 & -0.91 & 0.28 \\
0 & -0.02 & -0.08 & -0.70 & -0.83 & -0.70 \\
1 & 0.26 & 0.89 & -0.44 & -0.50 & 0.13 \\
2 & -0.06 & -0.21 & -0.50 & -0.52 & -0.88 \\
3 & 0.26 & 0.90 & -0.24 & -0.25 & 1.19 \\
4 & 0.23 & 0.81 & -0.01 & -0.01 & 0.49 \\
5 & 0.60 & $2.53^{* *}$ & 0.59 & 0.58 & $2.67 * *$ \\
6 & 0.23 & 0.80 & 0.82 & 0.75 & 0.32 \\
7 & -0.15 & -0.60 & 0.67 & 0.62 & -0.57 \\
8 & 0.11 & 0.33 & 0.78 & 0.66 & 0.05 \\
9 & 0.17 & 0.67 & 0.95 & 0.78 & -0.25 \\
0.07 & -0.25 & 0.88 & 0.73 & -0.10
\end{tabular}

\begin{tabular}{cccc} 
& CAAR(\%) & t(CAAR) & Wilcoxon Test \\
\hline$[-5,-1]$ & -0.46 & -0.78 & 0.12 \\
{$[-2,0]$} & 0.15 & 0.41 & 0.33 \\
{$[-1,0]$} & 0.18 & 0.53 & 0.07 \\
{$[-1,+1]$} & 0.44 & 1.03 & 0.67 \\
{$[0,+1]$} & 0.24 & 0.58 & 0.08 \\
{$[0,+5]$} & 1.27 & $1.94 *$ & $2.04 * *$ \\
{$[+1,+5]$} & 1.29 & $2.15^{* *}$ & $2.81^{* * *}$ \\
{$[+1,+9]$} & 1.65 & $2.03^{* *}$ & $1.87 *$ \\
{$[+1,+10]$} & 1.58 & $1.91^{*}$ & $2.08^{* *}$
\end{tabular}

Notes: This table displays the return effects of single announcements of subsequent CGR. Day 0 is the announcement (event) date. AAR $(\%)$ and CAAR(\%) abnormal return and cumulative abnormal return on average. $t(A A R)$ and $t(C A A R)$ represent the $t$ statistics. Non-parametric Wilcoxon signed-rank test statistics show whether the z statistic of AAR is significantly different from zero. $* * *, * *$ and

$*$ denote the significance level at $1 \%, 5 \%$ and $10 \%$, respectively. Sample includes 60 observations. 


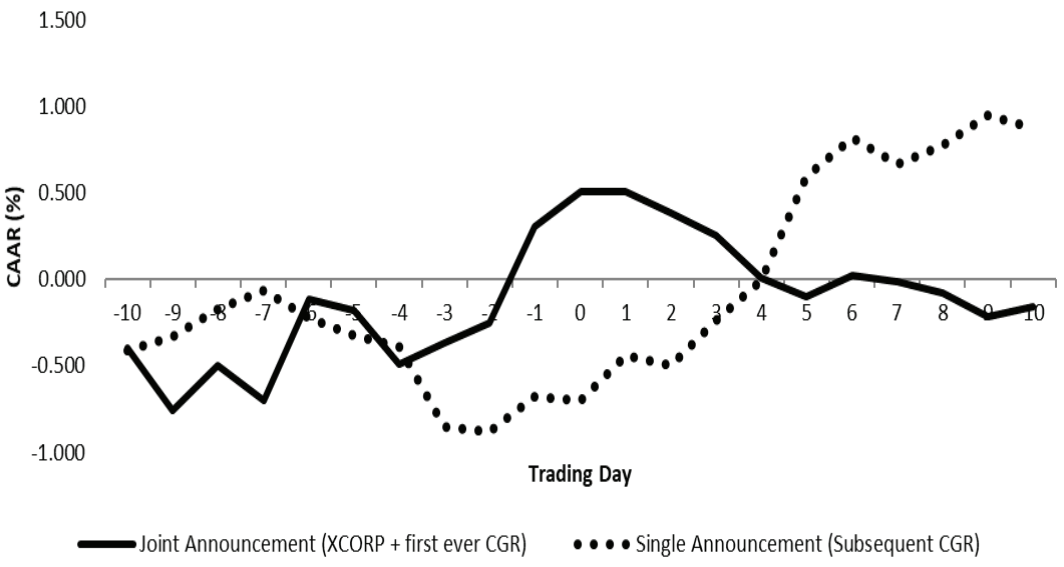

Figure 2. CAAR for the shares as XCORP inclusions along with first ever CGR and subsequent CGR are announced

\section{XCORP Inclusions and First Ever CGR versus Subsequent CGR}

At first sight, our results imply that the share price reaction to joint announcements of XCORP and first ever CGR was stronger than to single announcements of subsequent CGR in the pre-event period, while the situation was reversed in the aftermath of the announcement day. Table 7 presents the mean difference tests between these two types of announcements for a variety of event windows.

Table 7 suggests that abnormal returns associated with joint announcements were generally positive and economically greater than that of single announcements in the pre-event period and on the announcement date. However, the results proved statistically significant in the $[-1,0]$ period only in non-parametric terms. In the post-event period, more profound results were obtained in favor of subsequent CGR announcements both parametrically and non-parametrically. Taken together, our findings suggest the opposite of our preliminary evidence in that joint announcements in fact were not such strong signals when compared to single announcements in statistical terms, since we were able to capture mere significance even in the pre-event period, which disappeared immediately. This translates into suspicion of the entire superiority of subsequent CGR over first ever CGR owing to the fact that XCORP inclusions may have adverse informational effects on investors that act as a neutralizer, even reverser, for a probable overreaction to CGR. 
Table 7

Differences between price reaction of joint and single announcements

\begin{tabular}{|c|c|c|c|c|c|c|c|}
\hline \multirow{2}{*}{ Day } & \multicolumn{2}{|c|}{ Joint Announcements } & \multicolumn{2}{|c|}{ Single Announcements } & \multirow{2}{*}{$\begin{array}{c}\text { Two tailed } \\
\text { t-test }\end{array}$} & \multirow{2}{*}{ p-value } & \multirow[t]{2}{*}{ Wilcoxon test } \\
\hline & AAR & CAAR & AAR & CAAR & & & \\
\hline \multicolumn{8}{|l|}{$[-5,-1]$} \\
\hline Mean & 0.08 & 0.42 & -0.09 & -0.05 & & & \\
\hline t-stat. & 0.53 & & -0.78 & & 0.89 & 0.38 & 0.35 \\
\hline \multicolumn{8}{|l|}{$[-2,0]$} \\
\hline Mean & 0.29 & 0.88 & 0.05 & 0.15 & & & \\
\hline t-stat. & $1.73^{*}$ & & 0.41 & & 1.16 & 0.25 & 1.04 \\
\hline \multicolumn{8}{|l|}{$[-1,0]$} \\
\hline Mean & 0.38 & 0.76 & 0.09 & 0.18 & & & \\
\hline t-stat. & $2.22 * *$ & & 0.53 & & 1.21 & 0.23 & $1.85^{*}$ \\
\hline \multicolumn{8}{|l|}{$[-1,+1]$} \\
\hline Mean & 0.25 & 0.76 & 0.15 & 0.44 & & & \\
\hline t-stat. & 1.53 & & 1.03 & & 0.49 & 0.62 & 0.58 \\
\hline \multicolumn{8}{|l|}{$[0]$} \\
\hline Mean & 0.20 & 0.20 & -0.02 & -0.02 & & & \\
\hline t-stat. & 0.97 & & -0.08 & & 0.67 & 0.50 & 1.49 \\
\hline \multicolumn{8}{|l|}{$[0,+1]$} \\
\hline Mean & 0.10 & 0.20 & 0.12 & 0.24 & & & \\
\hline t-stat. & 0.39 & & 0.58 & & -0.05 & 0.96 & 0.07 \\
\hline \multicolumn{8}{|l|}{$[0,+5]$} \\
\hline Mean & -0.07 & -0.41 & 0.21 & 1.27 & & & \\
\hline t-stat. & -0.50 & & $1.94 *$ & & -1.60 & 0.11 & $-1.92 *$ \\
\hline \multicolumn{8}{|l|}{$[+1,+5]$} \\
\hline Mean & -0.01 & -0.61 & 0.26 & 1.29 & & & \\
\hline t-stat. & -0.84 & & $2.15^{* *}$ & & $-2.01 * *$ & 0.05 & $-2.54 * *$ \\
\hline \multicolumn{8}{|l|}{$[+1,+9]$} \\
\hline Mean & -0.08 & -0.73 & 0.18 & 1.65 & & & \\
\hline t-stat. & -0.78 & & $2.03 * *$ & & $-1.93 *$ & 0.06 & $-1.92 *$ \\
\hline \multicolumn{8}{|l|}{$[+1,+10]$} \\
\hline Mean & -0.07 & -0.67 & 0.16 & 1.58 & & & \\
\hline t-stat. & -0.72 & & $1.91^{*}$ & & $-1.81 *$ & 0.07 & $-1.89 *$ \\
\hline
\end{tabular}

Notes: This table displays the mean differences in average and cumulative abnormal returns for the joint announcements of XCORP and first ever CGR and single announcements of subsequent CGR with respect to several event windows. Two-tailed test statistics indicate the mean differences between abnormal returns induced by joint and single announcements. The next column is the p-value of this test. The last column stands for non-parametric tests measuring the significance of signs of parameters. $* *$ and $*$ denote the significance level at $5 \%$ and $10 \%$, respectively. Sample includes 60 observations.

\section{Volume Reactions to Announcements of XCORP Inclusions and CGR}

\section{XCORP Inclusions and First Ever CGR}

We employed the same methodology for announcement effects on trading volumes. The outcome of our analysis with respect to the joint announcements of XCORP inclusions and first ever CGR is portrayed in Table 8. The mean abnormal trading volume was greater than one in the $[-1,1]$ period but not statistically significant. This is broadly consistent with our 
findings regarding abnormal returns in Table 5. Similarly, this positive reaction faded away immediately after Day +1 . One significantly positive volume reaction (1.004) occurred on Day -4 next to a negative reaction $(0.982)$ on the previous Day -5 . Throughout the event window, we observed various days of abnormal volumes lower than one implying negative volume effects in the market. These results were, by and large, in parallel with the literature in that return and volume effects moved in the same direction (Bildik and Gülay, 2008). Nevertheless, the weak nature of volume effects are considered as signs of irrelevance of XCORP inclusions on the awareness of investors and on the liquidity in the market.

Table 8

Abnormal volumes around the announcement date of inclusion in XCORP

\begin{tabular}{lcccc}
\hline Day & MATV & t(MATV) & TV $\geq \mathbf{1}(\mathbf{\%})$ & p-value \\
\hline-10 & 1.003 & 0.34 & 49.15 & 0.60 \\
-9 & 1.001 & 0.09 & 44.07 & 0.85 \\
-8 & 1.003 & 0.32 & 49.15 & 0.60 \\
-7 & 1.009 & 0.89 & 50.85 & 0.50 \\
-6 & 0.994 & -0.72 & 47.46 & 0.70 \\
-5 & 0.982 & $-1.69 * *$ & 42.37 & 0.90 \\
-4 & 1.004 & 0.54 & 59.32 & $1.00^{*}$ \\
-3 & 0.993 & 38.98 & $0.97\left(^{*}\right)$ \\
-2 & 0.993 & -0.66 & 40.68 & $0.94\left(^{*}\right)$ \\
-1 & 1.001 & 0.59 & 0.78 \\
0 & 1.009 & 1.07 & 47.76 & 0.70 \\
1 & 1.010 & 0.91 & 44.07 & 0.85 \\
2 & 0.996 & -0.38 & 42.37 & 0.90 \\
3 & 0.995 & -0.58 & 49.15 & 0.60 \\
5 & 0.987 & -0.97 & 38.98 & $0.97\left(^{*}\right)$ \\
7 & 1.002 & 0.26 & 45.76 & 0.78 \\
9 & 1.009 & 0.82 & 49.15 & 0.60
\end{tabular}

Notes: This table displays the volume effects of joint announcements of XCORP and first ever CGR. Day 0 is the announcement (event) date. MATV is the mean abnormal trading volume. $t(M A T V)$ represents the one-tailed $t$ statistics for mean values of abnormal volume. ** denotes the significance level at $5 \% .4^{\text {th }}$ column shows the percentages of the abnormal volumes greater than 1 . Last column reports the p-values which tests whether the volume ratio is greater than $1 .{ }^{*}$ and $\left(^{*}\right)$ denote the significance level at $10 \%$ for the p-values of that volume ratio is greater and lower than 1, respectively. Sample includes 60 observations.

\section{Subsequent CGR}

In Table 9, volume reactions to subsequent CGR announcements are displayed. Similar to the results given in Table 6, a positive, but insignificant, abnormal trading volume was observed on Day +5 . However, a striking finding was that most of the negative abnormal volumes, particularly significant ones, were clustered around the announcement date. This pattern started on Day -5 and lasted for nine consecutive days until Day +5 when it died out. 
This does not properly coincide with Table 6 where positive data in abnormal returns are observed within the same interval (i.e. $0.20,0.26,0.26$ and 0.23 on Day -1 , Day +1 , Day +3 and Day +4 , respectively) and implies that some abnormal returns may have been attained with low levels of trading, partly explaining possible outliers in our data. But, as an extension to our concerns regarding the volume effects of XCORP inclusions above, it is more plausible to argue that CGR announcements were not widely followed in the market and they did not contribute to the liquidity of stocks either.

Table 9

Abnormal volumes around the announcement date of subsequent CGR

\begin{tabular}{lcccc}
\hline Day & MATV & t(MATV) & TV $\geq \mathbf{1}(\mathbf{\%})$ & p-value \\
\hline-10 & 0.997 & -0.43 & 44.07 & 0.85 \\
-9 & 0.992 & -0.86 & 35.59 & $\left.0.99^{* *}\right)$ \\
-8 & 1.003 & 0.32 & 44.07 & 0.85 \\
-7 & 1.005 & 0.71 & 50.85 & 0.50 \\
-6 & 1.006 & 0.66 & 45.76 & 0.78 \\
-5 & 0.985 & $-2.15^{* *}$ & 35.59 & $0.99\left(^{* *}\right)$ \\
-4 & -0.32 & 40.68 & $0.94\left(^{*}\right)$ \\
-3 & 0.997 & -0.41 & 44.07 & 0.85 \\
-2 & 0.996 & $-1.63^{*}$ & 33.90 & $\left.1.00^{(* *}\right)$ \\
-1 & 0.983 & $-2.02^{* *}$ & 37.29 & $0.98\left(^{* *}\right)$ \\
0 & 0.982 & $-1.65^{*}$ & 35.59 & $0.99\left(^{* *}\right)$ \\
1 & 0.982 & -0.52 & 33.90 & $1.00^{(* * *)}$ \\
2 & 0.994 & $-1.66^{*}$ & 38.98 & $0.97\left(^{*}\right)$ \\
3 & 0.983 & -0.18 & 45.76 & 0.78 \\
4 & 0.998 & $-1.65^{*}$ & 42.37 & 0.90 \\
5 & 0.985 & 0.34 & 47.46 & 0.70 \\
7 & 1.003 & -0.04 & 40.68 & $0.94\left(^{*}\right)$ \\
\hline & 1.000 & -0.32 & 40.68 & $0.94\left(^{* *}\right)$
\end{tabular}

Notes: This table displays the volume effects of joint announcements of subsequent CGR. Day 0 is the announcement (event) date. MATV is the mean abnormal trading volume. t(MATV) represents the one-tailed t statistics for mean values of abnormal volume. $* *$ and $*$ denote the significance level at $5 \%$ and $10 \%$, respectively. 4 th column shows the percentages of the abnormal volumes greater than 1. Last column reports the p-values which tests whether the volume ratio is greater than $1 .\left({ }^{* *}\right),\left({ }^{* *}\right)$ and $\left(^{*}\right)$ denote the significance level at $1 \%, 5 \%$ and $10 \%$ for the p-values of that volume ratio is lower than 1, respectively. Sample includes 60 observations.

\section{XCORP Inclusions and First Ever CGR versus Subsequent CGR}

Table 10 demonstrates the results of tests of differences in means between the abnormal volumes related to joint and single announcements. It is evident that the signaling effects of joint announcements on abnormal volume were economically stronger than that of single ones at all event periods. The results are statistically significant one day around the announcement date, predominantly in the period of $[-1,0]$ and on Day 0 as revealed by both parametric and non-parametric tests. 
Table 10

Differences between volume reaction of joint and single announcements

\begin{tabular}{|c|c|c|c|c|c|}
\hline Day & Joint Announcements & $\begin{array}{c}\text { Single } \\
\text { Announcements }\end{array}$ & $\begin{array}{l}\text { Two tailed } \\
\text { t-test }\end{array}$ & p-value & Wilcoxon test \\
\hline \multicolumn{6}{|l|}{$[-5,-1]$} \\
\hline Mean & 0.995 & 0.989 & & & \\
\hline t-stat. & -0.66 & $-1.79 *$ & 0.55 & 0.59 & 0.56 \\
\hline \multicolumn{6}{|l|}{$[-2,0]$} \\
\hline Mean & 1.001 & 0.983 & & & \\
\hline t-stat. & 0.13 & $-2.06^{* *}$ & 1.46 & 0.15 & 1.43 \\
\hline \multicolumn{6}{|l|}{$[-1,0]$} \\
\hline Mean & 1.005 & 0.983 & & & \\
\hline t-stat. & 0.57 & $-2.07 * *$ & $1.82 *$ & 0.07 & $1.85 *$ \\
\hline \multicolumn{6}{|l|}{$[-1,+1]$} \\
\hline Mean & 1.007 & 0.986 & & & \\
\hline t-stat. & 0.76 & -1.64 & $1.66^{*}$ & 0.10 & 1.56 \\
\hline \multicolumn{6}{|l|}{ [0] } \\
\hline Mean & 1.009 & 0.983 & & & \\
\hline t-stat. & 1.07 & -1.65 & $1.95^{*}$ & 0.05 & $2.36 * *$ \\
\hline \multicolumn{6}{|l|}{$[0,+1]$} \\
\hline Mean & 1.010 & 0.988 & & & \\
\hline t-stat. & 1.06 & -1.20 & 1.60 & 0.11 & $1.66^{*}$ \\
\hline \multicolumn{6}{|l|}{$[0,+5]$} \\
\hline Mean & 1.000 & 0.991 & & & \\
\hline t-stat. & 0.01 & -1.19 & 0.81 & 0.42 & 0.52 \\
\hline \multicolumn{6}{|l|}{$[+1,+5]$} \\
\hline Mean & 0.998 & 0.993 & & & \\
\hline t-stat. & -0.21 & -0.94 & 0.48 & 0.64 & 0.08 \\
\hline \multicolumn{6}{|l|}{$[+1,+9]$} \\
\hline Mean & 1.001 & 0.994 & & & \\
\hline t-stat. & 0.11 & -0.82 & 0.63 & 0.53 & 0.49 \\
\hline \multicolumn{6}{|l|}{$[+1,+10]$} \\
\hline Mean & 1.001 & 0.995 & & & \\
\hline t-stat. & 0.09 & -0.76 & 0.57 & 0.57 & 0.35 \\
\hline
\end{tabular}

Notes: This table displays the mean differences in abnormal trading volumes for the joint announcements of XCORP and first ever CGR and single announcements of subsequent CGR with respect to several event windows. Two-tailed test statistics indicate the mean differences between abnormal volumes induced by joint and single announcements. The next column is the p-value of this test. The last column stands for non-parametric tests measuring the significance of signs of parameters. ${ }^{* *}$ and $*$ denote the significance level at $5 \%$ and $10 \%$, respectively. Sample includes 60 observations.

Finally, we summarize the findings that indicate the effects of XCORP inclusion and CGR announcements on return and volume of the stocks in Table 11. 
Table 11

Summarized findings

\begin{tabular}{lcccccc}
\hline \multirow{2}{*}{$\begin{array}{l}\text { Time } \\
\text { period }\end{array}$} & $\begin{array}{c}\text { XCORP inclusion and first } \\
\text { ever CGR (1) }\end{array}$ & $\begin{array}{c}c \\
\text { Subsequent } \\
\text { CGR (2) }\end{array}$ & \multicolumn{2}{c}{ Difference (1)-(2) } \\
\cline { 2 - 7 } & Abnormal & $\begin{array}{c}\text { Abnormal } \\
\text { veturn }\end{array}$ & $\begin{array}{c}\text { Abnormal } \\
\text { return }\end{array}$ & $\begin{array}{c}\text { Abnormal } \\
\text { volume }\end{array}$ & $\begin{array}{c}\text { Abnormal } \\
\text { return }\end{array}$ & $\begin{array}{c}\text { Abnormal } \\
\text { volume }\end{array}$ \\
\hline Pre-event & $+*$ & $\uparrow$ & - & $\downarrow * *$ & $(1)>(2)^{*}$ & $(1)>(2)^{*}$ \\
Event day & + & $\uparrow$ & - & $\downarrow * *$ & $(1)>(2)$ & $(1)>(2)^{* *}$ \\
Post-event & - & $\downarrow$ & $+* *$ & $\downarrow *$ & $(2)>(1)^{* *}$ & $(1)>(2)$ \\
\hline
\end{tabular}

Notes: This table displays the summarized findings of the impact of announcements regarding XCORP inclusion and CGR on stock returns and trading volumes. $* *$ and $*$ denote the significance level at $5 \%$ and $10 \%$, respectively. Sample includes 60 observations.

Overall, one can easily realize that abnormal return and volume reactions to the joint announcements of XCORP inclusions and first ever CGR outweighed, though still with low significance, the reactions to the single announcements of subsequent CGR in the preevent period and on the announcement day. In the post-event period, while abnormal return reactions were stronger for subsequent CGR announcements, their volume reactions were fairly weaker. We critically interpreted these periodic differences between first ever (joint announcements) and subsequent CGR (single announcements) as resulting from the suppressive effects of XCORP inclusion. Conceptually speaking, the anticipated feature of XCORP inclusion may be obscuring the value creating potential of CGR activity alone. The market typically expects XCORP inclusion since it is perceived as a formal announcement of a regulatory action rather than a voluntary corporate one (Binder, 1998). This is reasonable because regulatory changes (e.g. development of XCORP, incentives to be granted etc.) are often debated in investment circles over time and any accompanying wealth effects generally would gradually be incorporated into the value of a firm as the probability of the change being adopted increases (MacKinlay, 1997; Kothari and Warner, 2007). Apart from this, the reason why the market reaction to corporate governance announcements in Turkey as a whole is not so strong is mainly based on the general irrelevance of CGR for investor attention and market liquidity. This is probably due to the fact that CGR activity is so imitable that it cancels out first-mover advantages and firms are pressured into adopting corporate governance principles regardless of their performance effects (Rubach and Picou, 2005). One of the issues may be due to the statutory weightings for corporate governance subsections, which may be imposing certain restrictions on the professional judgments of rating agencies to some extent (Tsipouri and Xanthakis, 2004) and even may create inconsistency among investors that attach weights different than the statutory ones (Bhagat et al., 2008).

\section{Conclusion}

Corporate governance rating activity converges the complicated nature of corporate governance mechanism to a single figure. This service is a commercial one, voluntarily utilized by firms, primarily in order to attract investors. However, as more and more firms are rated 
over time, voluntary practices may become the norm. A special index, i.e. XCORP, designed for firms with acceptable rating scores in Turkish capital markets provides a unique experience in that respect. Investors are able to follow the price and return performances of their investments included in this specific index in comparison with the ones of non-rated firms.

We intend to answer the question of whether these investors attribute more importance to jointly announced XCORP inclusions with the first ever CGR or to individually announced subsequent CGR. Following an event study methodology, we found that joint announcements were associated with stronger positive abnormal returns and volumes in the pre-event period. The occurrence of such an information leakage is likely because XCORP inclusion is partially expected in the market beforehand. On the other hand, post-event period results revealed that subsequent CGR, which are unexpected as a matter of course, had the potential to create value for investors since abnormal returns were positive even though this was not reflected in volumes. Nevertheless, the relatively weak significant results obtained in our tests were attributable to current legislation and market practices, which appear to blur the relevance of CGR activity for investors.

Our findings offer at least two key policy implications: (1) enhancing corporate governance systems especially in emerging markets by means of effective regulations on CGR and index inclusion facility in their jurisdictions, (2) creating index funds that track XCORP or CGR of firms. For the former, regulations regarding CGR methodology should be based on prudence rather than firm obligations. For instance, statutory weightings for corporate governance subsections may hinder the required flexibility in rating business. Weights should be assigned by rating agencies upon professional judgment made with respect to certain firm characteristics. Otherwise, rating grades would show an increasing and converging trend in order to succeed in getting high scores particularly for subsections for which regulations attach more importance. This would inevitably trivialize the CGR activity in the eyes of investors. Furthermore, statutory weights may not be consistent with the weights used by market participants in assessing the relation between governance and firm performance. Hence, they may lead to incorrect inferences by investors. For the latter, institutional investors such as index funds and exchange traded funds, which track XCORP or are engaged with CGR, should be activated to create impact on the stock market. These investors would be more willing to have their investments maintain high CGR since they have to stick to their portfolio strategies. One important progress in this respect is the recent regulation that obligates at least $10 \%$ of the state contribution in pension funds to be invested in stocks included in specific indices such as XCORP. Undoubtedly, the presence of like initiatives would enhance investor awareness and market liquidity.

This study is not without its limitations. First, we were only able to uncover the importance of joint announcements relative to single announcements. However, we lacked empir- 
ical data to provide an answer as to which of the parts of the joint announcements is more dominant. This is predominantly because corporate governance requirements in Turkey, as discussed earlier, do not allow us to compare firms jointly announcing the XCORP inclusion and the first ever CGR with the firms announcing CGR without an intention for XCORP inclusion. Hence, we confine ourselves to make an empirical comparison between the joint (i.e. XCORP and CGR) and single (i.e. CGR) announcements of the same firms rather than comparing the subject firms with each other. In other words, our analytical framework was based solely on the measurement of an overall reaction in lieu of assessing the exact contribution of XCORP inclusion and the first ever CGR separately with a more robust, e.g. a conditional event study or regression technique. Another limitation is pertinent to the small sample size. Although a considerable amount of CGR data exists, XCORP inclusions are relatively rare. This constitutes a natural constraint on the number of joint announcements as opposed to an abundance of single CGR announcements. Finally, yet importantly, our results are subject to the usual limitations of event studies. For instance, although we put in place relevant controls, there could still be some noise due to confounding events. We leave further analyses focusing on disentangling the informational content of two events as well as possible effects of CGR activities on liquidity and volatility for future research.

Peer-review: Externally peer-reviewed.

Conflict of Interest: The authors have no conflict of interest to declare.

Grant Support: The authors declared that this study has received no financial support.

\section{References}

Al-ahdal, W. M., Alsamhi, M. H., Tabash, M. I., \& Farhan, N. H. (2020). The impact of corporate governance on financial performance of Indian and GCC listed firms: An empirical investigation. Research in International Business and Finance, 51, 101083.

Al-Yahyaee, K. H., Pham, T. M., \& Walter, T. S. (2011). The information content of cash dividend announcements in a unique environment. Journal of Banking \& Finance, 35(3), 606-612.

Anand, A. (2006). An Analysis of Enabling vs. Mandatory Corporate Governance Structures Post-SarbanesOxley. Delaware Journal of Corporate Law, 31(1), 229-252.

Anderson, W. (2009). Alternative event study methodology for detecting dividend signals in the context of joint dividend and earnings announcements. Accounting \& Finance, 49(2), 247-265.

Ararat, M., Black, B. S., \& Yurtoglu, B. B. (2017). The effect of corporate governance on firm value and profitability: Time-series evidence from Turkey. Emerging Markets Review, 30, 113-132.

Armitage, S. (1995). Event study methods and evidence on their performance. Journal of Economic Surveys, 9, 25-52.

Arora, A., \& Bodhanwala, S. (2018). Relationship between Corporate Governance Index and Firm Performance: Indian Evidence. Global Business Review, 19(3), 675-689. 
Arora, A., \& Sharma, C. (2016). Corporate governance and firm performance in developing countries: evidence from India. Corporate governance.

Ataman, B., Gökçen, G., Cavlak, H., \& Cebeci, Y. (2017). Analysis of the Relationship Between Corporate Governance Perception and Corporate Governance Rating. Journal of Finance Letters, 31(107), 161-185.

Basdas, U., \& Oran, A. (2014). Event studies in Turkey. Borsa Istanbul Review, 14(3), 167-188.

Bauer, R., Guenster, N., \& Otten, R. (2004). Empirical evidence on corporate governance in Europe: the effect on stock returns, firm value and performance. Journal of Asset Management, 5(2), 91-104.

Bebchuk, L., Cohen, A., \& Ferrell, A. (2009). What matters in corporate governance?. The Review of financial studies, 22(2), 783-827.

Bhagat, S., Bolton, B., \& Romano, R. (2008). The promise and peril of corporate governance indices. Colum. L. Rev., 108, 1803-1882.

Bhatt, P. R., \& Bhatt, R. R. (2017). Corporate governance and firm performance in Malaysia. Corporate Governance: The international journal of business in society.

Bhattacharya, S. (1979). Imperfect information, dividend policy and "the bird in hand" fallacy. The Bell Journal of Economics, 10(1), 259-270.

Bildik, R., \& Gülay, G. (2008). The effects of changes in index composition on stock prices and volume: Evidence from the Istanbul stock exchange. International Review of Financial Analysis, 17(1), 178-197.

Binder, J. (1998). The event study methodology since 1969. Review of quantitative Finance and Accounting, 11(2), 111-137.

Black, B., De Carvalho, A. G., Khanna, V., Kim, W., \& Yurtoglu, B. (2014). Methods for multicountry studies of corporate governance: Evidence from the BRIKT countries. Journal of Econometrics, 183(2), 230-240.

Black, B., \& Khanna, V. (2007). Can Corporate Governance Reforms Increase Firm Market Values? Event Study Evidence from India. Journal of Empirical Legal Studies, 4(4), 749-796.

Black, B., Love, I., \& Rachinsky, A. (2006). Corporate governance indices and firms' market values: Time series evidence from Russia. Emerging Markets Review, 7(4), 361-379.

Bozcuk, A. (2010). Price reaction to corporate governance rating announcements at the Istanbul Stock Exchange. International Journal of Economics and Finance Studies, 2(1), 1-6.

Certo, S., Daily, C., \& Dalton, D. (2001). Signaling firm value through board structure: An investigation of initial public offerings. Entrepreneurship Theory and Practice, 26(2), 33-50.

Chang, R.-D., \& Wei, J.-T. (2011). Effects of governance on investment decisions and perceptions of reporting credibility: Investment experience of Taiwanese individual investors. Asia Pacific Journal of Management, 28(1), 139-155.

Chan-Lau, J. (2002). Corporate restructuring in Japan: an event-study analysis. Japan and the World Economy, 14(4), 367-377.

Cheung, Y., Connelly, J., Jiang, P., \& Limpaphayom, P. (2011). Does corporate governance predict future performance? Evidence from Hong Kong. Financial Management, 40(1), 159-197.

Cohen, B. D., \& Dean, T. J. (2005). Information asymmetry and investor valuation of IPOs: top management team legitimacy as a capital market signal. Strategic Management Journal, 26, 683-690.

Connelly, B., Certo, S., Ireland, R., \& Reutzel, C. (2011). Signaling Theory: A Review and Assessment. Journal of Management, 37(1), 39-67. 
Da Silva, A., \& Leal, R. (2005). Corporate governance index, firm valuation and performance in Brazil. Brazilian Review of Finance, 3(1), 1-18.

Daines, R., Gow, I., \& Larcker, D. (2010). Rating the ratings: How good are commercial governance ratings? Journal of Financial Economics, 98(3), 439-461.

Dasilas, A., Lyroudi, K., \& Ginoglou, D. (2008). Joint effects of interim dividend and earnings announcements in Greece. Studies in Economics and Finance, 25(4), 212-232.

Diamond, D. (1985). Optimal release of information by firms. Journal of Finance, 40(4), 1071-1094.

Donker, H., \& Zahir, S. (2008). Towards an impartial and effective corporate governance rating system. Corporate Governance: The international journal of business in society, 8(1), 83-93.

Drobetz, W., Schillhofer, A., \& Zimmermann, H. (2004). Corporate governance and expected stock returns: Evidence from Germany. European financial management, 10(2), 267-293.

Easton, S. (1991). Earnings and dividends: Is there an interaction effect? Journal of Business, Finance and Accounting, 18, 255-266.

Eddy, A., \& Seifert, B. (1992). Stock price reactions to dividend and earnings announcements: contemporaneous versus noncontemporaneous announcements. Journal of Financial Research, 15(3), 201-217.

Epps, R., \& Cereola, S. (2008). Do institutional shareholder services (ISS) corporate governance ratings reflect a company's operating performance? Critical Perspectives on Accounting, 19(8), 1135-1148.

Ernst\&Young. (2016). Corporate Governance Challenges in Peru towards the Pacific Alliance. Lima: Ernst\&Young.

Ertugrul, M., \& Hegde, S. (2009). Corporate governance ratings and firm performance. Financial Management, 38(1), 139-160.

Fama, E. (1965). The behavior of stock market prices. Journal of Business, 38, 34-105.

Foerster, S., \& Huen, B. (2004). Does corporate governance matter to Canadian investors? Canadian Investment Review, Fall, 19-25.

Fuenzalida, D., Mongrut, S., Arteaga, J., \& Erausquin, A. (2013). Good corporate governance: Does it pay in Peru? Journal of Business Research, 66, 1759-1770.

Garay, U., \& Gonzalez, M. (2008). Corporate Governance and Firm Value: The Case of Venezuela. Corporate Governance: An International Review, 16(3), 194-209.

George, J. M., \& Jones, G. R. (2000). The Role of Time in Theory and Theory Building. Journal of Management, 26(4), 657-684.

Ghosh, S. (2018). Governance reforms and performance of MENA banks: Are disclosures effective?. Global Finance Journal, 36, 78-95.

Gillan, S. L. (2006). Recent Developments in Corporate Governance: An Overview. Journal of Corporate Finance, 12(3), 381-402.

Gompers, P., Ishii, J., \& Metrick, A. (2003). Corporate governance and equity prices. Quarterly Journal of Economics, 118(1), 107-155.

Guest, P. M., \& Nerino, M. (2020). Do Corporate Governance Ratings Change Investor Expectations? Evidence from Announcements by Institutional Shareholder Services. Review of Finance, 24(4), 891-928.

Gupta, M., \& Fields, L. P. (2009). Board Independence and Corporate Governance: Evidence from Director Resignations. Journal of Business Finance \& Accounting, 36(1-2), 161-184. 
Harris, L., \& Gürel, E. (1986). Price and volume effects associated with changes in the S\&P 500 list: New evidence for the existence of price pressures. The Journal of Finance, 41(4), 815-829.

Heil, O., \& Robertson, T. (1991). Toward a theory of competitive market signalling: A research agenda. Strategic Management Journal, 12, 403-418.

Hodgson, A., Lhaopadchan, S., \& Buakes, S. (2011). How informative is the Thai corporate governance index? A financial approach. International Journal of Accounting \& Information Management, 19(1), 53-79.

Jensen, M. (1978). Some anomalous evidence regarding market efficiency. Journal of Financial Economics, 6, 95-101.

Kalaignanam, K., \& Bahadir, S. C. (2013). Corporate brand name changes and business restructuring: is the relationship complementary or substitutive?. Journal of the Academy of Marketing Science, 41(4), 456-472.

Kane, A., Lee, Y., \& Marcus, A. (1984). Earnings and dividend announcements: is there a corroboration effect? The Journal of Finance, 39(4), 1091-1099.

Kang, E., Ding, D. K., \& Charoenwong, C. (2009). Investor reaction to women directors. Journal of Business Research, 63(8), 888-894.

Kaur, M., \& Vij, M. (2018). Corporate governance index and firm performance: empirical evidence from Indian banking. Afro-Asian Journal of Finance and Accounting, 8(2), 190-207.

Kavcar, B., \& Gümrah, Ü. (2017). Corporate Governance Principles Compliance and Firm Value in Istanbul Stock Exchange: Case study. International Journal of Economic \& Social Research, 13(1).

Kilıç, S. (2011), Measuring the Return Performances of the Companies Included in ISE Corporate Governance Index. Finans Politik \& Ekonomik Yorumlar, 48(552).

Koehn, D., \& Ueng, J. (2005). Evaluating the evaluators: should investors trust corporate governance metrics ratings? Journal of Management \& Governance, 9(2), 111-128.

Korent, D., Đunđek, I., \& Klačmer Čalopa, M. (2014). Corporate governance practices and firm performance measured by Croatian Corporate Governance Index (CCGI $\left.{ }^{2}\right)$. Economic research-Ekonomska istraživanja, 27(1), 221-231.

Kothari, S. P., \& Warner, J. B. (2007). Econometrics of event studies. In Handbook of empirical corporate finance (pp. 3-36). Elsevier.

Kouwenberg, R., \& Phunnarungsi, V. (2013). Corporate governance, violations and market reactions. Pacific-Basin Finance Journal, 21(1), 881-898.

Lee, P. M. (2001). What's in a name .com? The effects of ".com" name changes on stock prices and trading activity. Strategic Management Journal, 22, 793-804.

Lehn, K., Patro, S., \& Zhao, M. (2007). Governance indexes and valuation: which causes which?. Journal of Corporate Finance, 13(5), 907-928.

Litvak, K. (2007). The effect of the Sarbanes-Oxley act on non-US companies cross-listed in the US. Journal of Corporate Finance, 13(2-3), 195-228.

Lonie, A., Abeyratna, G., Power, D., \& Sinclair, C. (1996). The stock market reaction to dividend announcements. Journal of Economic Studies, 23(1), 32-52.

MacKinlay, A. (1997). Event Studies in Economics and Finance. Journal of Economic Literature, 35(1), 13-39.

McCluskey, T., Burton, B., Power, D., \& Sinclair, C. (2006). Evidence on the Irish stock market's reaction to dividend announcements. Applied Financial Economics, 16(8), 617-628. 
McWilliams, A., \& Siegel, D. (1997). Event Studies in Management Research: Theoretical and Empirical Issues. The Academy of Management Journal, 40(3), 626-657.

Miller, M., \& Rock, K. (1985). Dividend policy under asymmetric information. The Journal of finance, 40(4), 1031-1051.

Morey, M., Gottesman, A., Baker, E., \& Godridge, B. (2009). Does better corporate governance result in higher valuations in emerging markets? Another examination using a new data set. Journal of Banking \& Finance, 33(2), 254-262.

Musteen, M., Datta, D., \& Kemmerer, B. (2010). Corporate reputation: do board characteristics matter? British Journal of Management, 21(2), 498-510.

Nayak, S., \& Prabhala, N. (2001). Disentangling the Dividend Information in Splits: A Decomposition Using Conditional Event-Study Methods. The Review of Financial Studies, 14(4), 1083-1116.

OECD. (2006). Corporate Governance in Turkey: A Pilot Study. OECD Publishing.

OECD. (2013). Supervision and Enforcement in Corporate Governance. OECD Publishing.

OECD. (2015). G20/OECD Principles of Corporate Governance. Paris: OECD Publishing.

OECD. (2017). OECD Corporate Governance Factbook 2017. OECD.

Ozo, F. K., \& Arun, T. G. (2019). Stock market reaction to cash dividends: evidence from the Nigerian stock market. Managerial Finance, 45(3), 366-380.

Park, N. K., \& Mezias, J. M. (2005). Before and after the technology sector crash: the effect of environmental munificence on stock market response to alliances to e-commerce firms. Strategic Management Journal, 26, 987-1007.

Peterson, P. (1989). Event studies: A review of issues and method. Quarterly Journal of Business and Economics, 28(3), 36-66.

Picou, A., \& Rubach, M. J. (2006). Does Good Governance Matter to Institutional Investors? Evidence from the Enactment of Corporate Governance Guidelines. Journal of Business Ethics, 65, 55-67.

Rahaman, M., \& Al Zaman, A. (2013). Management quality and the cost of debt: Does management matter to lenders? Journal of Banking \& Finance, 37(3), 854-874.

Renders, A., Ann, G., \& Piet, S. (2010). Corporate-Governance Ratings and Company Performance: A CrossEuropean Study. Corporate Governance: An International Review, 18(2), 87-106.

Ross, S. (1977). The determination of financial structure: The incentive signalling approach. The Bell Journal of Economics, 8(1), 23-40.

Rubach, M., \& Picou, A. (2005). The enactment of corporate governance guidelines: an empirical examination. Corporate Governance, 5(5), 30-38.

Sakarya, Ş. (2011). The Rating Scores of The Enterprises in Scope Of The ISE Corporate Governance Index and the Analysis of Relations Between the Stock Returns with the Event Study Method, ZKU Journal of Social Sciences, 7(13), 147-162.

Sakarya, Ş., Yazgan, K. F., \& Yildirim, H. H. (2017). The Effect of Corporate Governance Ratings on The Share Performance: An Investigation from BIST Corporate Governance Index. Journal of Social Sciences and Humanities Researches, 19(40), 55-76.

Singh, M., \& Davidson III, W. N. (2003). Agency costs, ownership structure and corporate governance mechanisms. Journal of Banking \& Finance, 27(5), 793-816.

Spence, M. (1973). Job Market Signaling. The Quarterly Journal of Economics, 87(3), 355-374. 
TKYD. (2015). Kurumsal Yönetim Alg1 Araştırması (in Turkish), TKYD \& StratejiCo., Retrieved from https://www.kobirate.com.tr/content/KURUMSAL-YONETIM-ALGI-ARASTIRMASI.pdf.

Toms, J. (2002). Firm resources, quality signals and the determinants of corporate environmental reputation: some UK evidence. The British Accounting Review, 34(3), 257-282.

Tsipouri, L., \& Xanthakis, M. (2004). Can corporate governance be rated? Ideas based on the Greek experience. Corporate Governance: An International Review, 12(1), 16-28.

Tuan, K., \& Borak, M. (2019). Market Reactions Following Corporate Governance Rating Changes: Evidence from the Istanbul Stock Exchange. Ataturk University Journal of Economics \& Administrative Sciences, 33(3).

Utrero-González, N., \& J. Callado-Muñoz, F. (2016). Do investors react to corporate governance news? An empirical analysis for the Spanish market. BRQ Business Research Quarterly, 19(1), 13-25.

Venkatesh, P., \& Chiang, R. (1986). Information Asymmetry and the Dealer's Bid-Ask Spread: A Case Study of Earnings and Dividend Announcements. The Journal of Finance, 41(5), 1089-1102.

Westphal, J., \& Zajac, E. (1998). The Symbolic Management of Stockholders: Corporate Governance Reforms and Shareholder Reactions. Administrative Science Quarterly, 43(1), 127-153.

Yapa, K. (2017). The Effect of the Corporate Governance Rating's Announcement on the Stock Returns of Firms in BIST Corporate Governance Index. Uşak University Journal of Social Sciences, 10(3), 437-458.

Yavuz, S., Yildirim, S., \& Elmas, B. (2015). The Relation Between the Corporate Governance Index and the Profit of Companies' Stocks: An Application in BIST. Erzincan University Journal of the Institute of Social Sciences, 8(2), 73-82.

Yıldı, Y., Karan, M. B., \& Pirgaip, B. (2017). Market reaction to grouping equities in stock markets: An empirical analysis on Borsa Istanbul. Borsa Istanbul Review, 17(4), 216-227.

Zhang, H. (2005). Share price performance following actual share repurchases. Journal of Banking \& Finance, 29(7), 1887-1901.

Zhang, I. X. (2007). Economic consequences of the Sarbanes-Oxley Act of 2002. Journal of accounting and economics, 44(1-2), 74-115. 